Case Report

\title{
Management of Choroidal Neovascularization Associated with Optic Disc Melanocytoma with Intravitreal Aflibercept: A Case Report and Review of the Literature
}

\author{
Hany S. Hamza, ${ }^{1}$ Magdy Moussa, ${ }^{2}$ and Abdelrahman M. Elhusseiny $\mathbb{D}^{1,3}$ \\ ${ }^{1}$ Department of Ophthalmology, Kasr Al-Ainy School of Medicine, Cairo University, Egypt \\ ${ }^{2}$ Department of Ophthalmology, Tanta University, Egypt \\ ${ }^{3}$ Department of Ophthalmology, Bascom Palmer Eye Institute, University of Miami Miller School of Medicine, \\ 900 NW 17 Street, Miami, FL 33136, USA
}

Correspondence should be addressed to Abdelrahman M. Elhusseiny; aelhusseiny@postgrad.kasralainy.edu.eg

Received 31 May 2019; Accepted 18 July 2019; Published 7 August 2019

Academic Editor: Takaaki Hayashi

Copyright (c) 2019 Hany S. Hamza et al. This is an open access article distributed under the Creative Commons Attribution License, which permits unrestricted use, distribution, and reproduction in any medium, provided the original work is properly cited.

Purpose. To report a rare case of melanocytoma associated choroidal neovascularization (CNV) treated with intravitreal aflibercept. Methods. We reviewed the literature for the previous reports and different methods of treatment. Results. Optic disc melanocytoma has been considered as a benign melanocytic tumor that rarely affects vision. There is evidence in the literature of association between choroidal neovascular membrane and disc melanocytoma. Conclusions. In conclusion, our article provides a review of literature of such a rare association in which the ophthalmologists must be aware of its occurrence and possible ways of management.

\section{Introduction}

The optic disc melanocytoma 'magnocellular nevus of optic disc' is a rare benign melanocytic tumor that is usually innocent but sometimes it is difficult to be differentiated from juxta-papillary choroidal melanoma $[1,2]$. It usually does not affect vision. However, visual impairment may occur in some cases secondary to vascular occlusion or rarely malignant transformation $[1,2]$. Association between optic disc melanocytoma and choroidal neovascularization should be considered as one of the possible causes of diminution of vision in such patients. Different treatment options have been reported to be effective in treatment of such condition. This is a report of a case of optic disc melanocytoma presented with diminution of vision secondary to choroidal neovascularization (CNV), and intravitreal aflibercept was effective in the management of the associated CNV.

\section{Case Report}

A 51-year-old male presented with a recent diminution of vision in his left eye of 2-month duration. The examination of the right eye was unremarkable. The ocular examination of the left eye disclosed a normal anterior segment, free ocular motility. The visual acuity of the left eye was 20/200. The fundus examination revealed a darkly pigmented mass with feathery margins on the superonasal aspect of the optic disc associated with a yellow peripapillary mass, intraretinal hemorrhages, and retinal edema adjacent to the temporal side of optic disc. Malignant transformation of melanocytoma was excluded based on absence of hemorrhage on the surface of the lesion or any signs of necrosis. Fluorescein angiography of left eye showed hypofluoresence of melanocytoma associated with early hyperfluorescence and late leakage in the temporal juxtapapillary area with deep retinal hemorrhage (Figure 1). Optical coherence tomography (OCT) showed diffuse macular thickening measuring about 800 microns with spongy edema, focal elevation of the retinal pigment epithelium temporal to the disc, and a shallow subfoveal neurosensory detachment, with absence of 'double layer sign' (Figure 2(a)). Decision was taken to inject the patient with three intravitreal antivascular Endothelial Growth Factor (anti-VEGF) injections aflibercept (Eylea) one month apart between each of these injections. The visual acuity was 


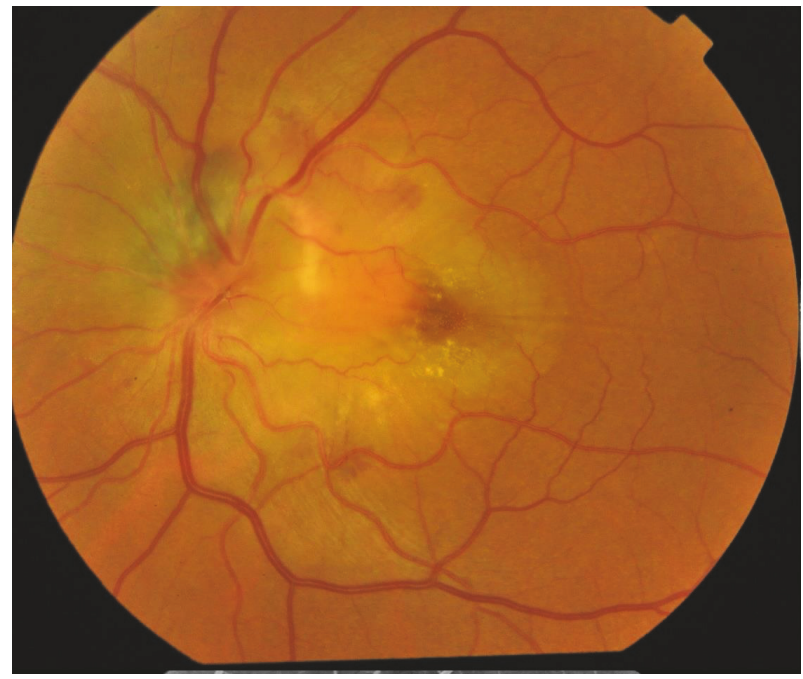

(a)

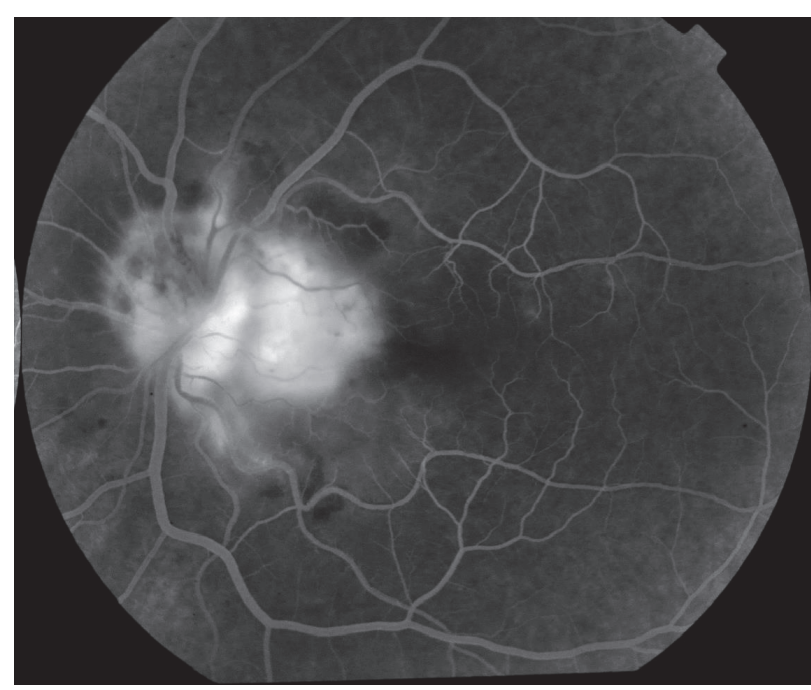

(b)

FIGURE 1: (a) Fluorescein angiography of the left eye showing early hyperfluorescence in the temporal juxtapapillary region. (b) Fundus photography of the left eye.

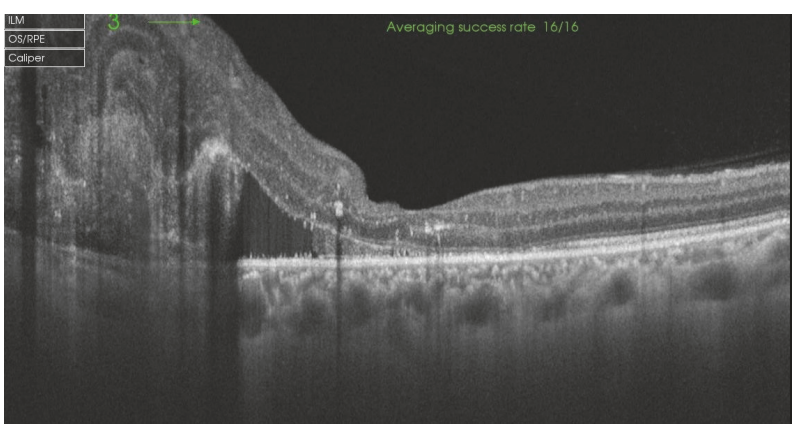

(a)



(b)

Figure 2: (a) Optical coherence tomography (OCT) showing diffuse macular thickening. (b) OCT showing complete resolution of the macular edema.

improved to 20/40 using Snellen's chart. OCT was done one month after last injection showed complete resolution of macular edema (Figure 2(b)). At the 13-month followup period, the visual acuity is still $20 / 40$ and dimensions of melanocytoma remained unchanged.

\section{Discussion}

Optic disc melanocytoma is a benign pigmented tumor arising from melanocytes that rarely affects vision. The most common site of melanocytoma is the optic disc; however it may rarely arise in the orbit. [10] In a minority of patients, complications may develop such as vascular occlusion, choroidal neovascularization, polypoidal choroidal vasculopathy (PCV), visual field defects, afferent pupillary defect, or rarely malignant transformation $[1,2]$. Choroidal neovascularization (CNV) is a variant of wet age-related macular degeneration. The association between PCV and optic disc melanocytoma has been rarely reported, with only 2 case reports in literature $[11,12]$. In our case, absence of the "double layer sign," a typical sign of PCV on OCT, makes the diagnosis of PCV unlikely in our patient. OCTAngiography was performed, and it did not show branching vascular network of PCV. These findings make the diagnosis of CNV more likely. However, it would have been better to do indocyanine green angiography to confirm the diagnosis and exclude PCV. CNV has been previously reported to be associated with optic disc melanocytoma with good response to intravitreal bevacizumab and ranibizumab as a method of treatment $[3-8,13]$. To our knowledge, this the first case report to demonstrate the efficacy of aflibercept in the management of choroidal neovascularization associated with optic disc melanocytoma.

There are several methods of management choroidal neovascular membrane associated with optic disc melanocytoma including photodynamic therapy, submacular surgery, and intravitreal anti-VEGF injection [3, 4, 9] (Table 1).

Less than $1 \%$ of cases of optic disc melanocytoma have been associated with CNV [13]. Although the relation between both signs is unclear, we agree with Kamisasaku 
TABLE 1: Review of previous reports on melanocytoma associated choroidal neovascularization (CNV).

\begin{tabular}{|c|c|c|c|c|c|c|c|c|}
\hline Case & $\begin{array}{c}\text { Chalam [3], } \\
2006\end{array}$ & $\begin{array}{c}\text { Tran [4], } \\
2006\end{array}$ & $\begin{array}{c}\text { Kamisasaku } \\
{[5],} \\
2012 \\
\end{array}$ & $\begin{array}{c}\text { Al-Halafi } \\
\text { [6], } \\
2013 \\
\end{array}$ & $\begin{array}{l}\text { Batmanabane } \\
\text { et al. [7] }\end{array}$ & $\begin{array}{l}\text { Urrets- } \\
\text { Zavalia } \\
{[8]}\end{array}$ & Rodrigues [9] & Current case \\
\hline Age & Middle age & 45 years & 63 years & 45 years & 28 years & 50 years & 49 years & 51 years \\
\hline Gender & Male & - & Male & Male & Female & Male & Female & Male \\
\hline Affected eye & Right & left & Left & Right & Left & Right & Left & Left \\
\hline $\begin{array}{l}\text { Primary } \\
\text { presentation }\end{array}$ & $\begin{array}{l}\text { Diminution of } \\
\text { vision }\end{array}$ & $\begin{array}{l}\text { Diminution } \\
\text { of vision }\end{array}$ & $\begin{array}{l}\text { Diminution } \\
\text { of vision }\end{array}$ & $\begin{array}{l}\text { Diminution } \\
\text { of vision }\end{array}$ & $\begin{array}{l}\text { Diminution } \\
\text { of vision }\end{array}$ & $\begin{array}{c}\text { Diminution } \\
\text { of vision }\end{array}$ & $\begin{array}{c}\text { Diminution of } \\
\text { vision }\end{array}$ & $\begin{array}{l}\text { Diminution } \\
\text { of vision }\end{array}$ \\
\hline $\begin{array}{l}\text { Visual Acuity at } 1^{\text {st }} \\
\text { presentation }\end{array}$ & $20 / 200$ & $20 / 100$ & $\begin{array}{c}0.9 \\
\text { LogMAR }\end{array}$ & $20 / 160$ & $20 / 40$ & $20 / 80$ & $\begin{array}{c}\text { Counting } \\
\text { fingers } 50 \mathrm{~cm}\end{array}$ & $20 / 200$ \\
\hline $\begin{array}{l}\text { Location of } \\
\text { choroidal } \\
\text { neovascularization }\end{array}$ & Juxtafoveal & Peripapilla y & $\begin{array}{l}\text { Adjacent to } \\
\text { optic disc }\end{array}$ & Juxtafoveal & $\begin{array}{l}\text { Peripapillary } \\
\text { extending to } \\
\text { the macula }\end{array}$ & Peripapillary & Macular & Peripapillary \\
\hline Treatment & $\begin{array}{l}\text { Photodynamic } \\
\text { therapy }\end{array}$ & $\begin{array}{l}\text { Vitrectomy } \\
\text { and } \\
\text { submacular } \\
\text { surgery } \\
\end{array}$ & $\begin{array}{l}\text { Intravitreal } \\
\text { Beva- } \\
\text { cizumab (3 } \\
\text { injections) } \\
\end{array}$ & $\begin{array}{l}\text { Intravitreal } \\
\text { Beva- } \\
\text { cizumab (1 } \\
\text { injection) } \\
\end{array}$ & $\begin{array}{c}\text { Intravitreal } \\
\text { Ranibizumab } \\
\text { (1 injection) }\end{array}$ & $\begin{array}{c}\text { Intravitreal } \\
\text { Bevacizumab }\end{array}$ & $\begin{array}{c}\text { Intravitreal } \\
\text { anti-VEGF was } \\
\text { recommended }\end{array}$ & $\begin{array}{c}\text { Intravitreal } \\
\text { Aflibercept (3 } \\
\text { injections) }\end{array}$ \\
\hline Follow-up & 6 months & 14 months & 12 months & 12 months & 6 months & 36 months & Lost to follow- & 13 months \\
\hline
\end{tabular}

et al. who postulated that the tumor may produce local inflammatory mediators disrupting the function of Bruch's membrane stimulating the choroid to produce a neovascular complex [5].

Intravitreal aflibercept is effective in treatment of $\mathrm{CNV}$ associated with disc melanocytoma.

\section{Conflicts of Interest}

The authors declare that they have no conflicts of interest.

\section{References}

[1] H. Hamza and A. Elhusseiny, "Choroidal melanoma resection," Middle East African Journal of Ophthalmology, vol. 25, no. 2, p. 65, 2018.

[2] L. Joffe, J. A. Shields, R. H. Osher, and J. D. M. Gass, "Clinical and follow-up studies of melanocytomas of the optic disc," Ophthalmology, vol. 86, no. 6, pp. 1067-1083, 1979.

[3] K. Chalam, S. Gupta, G. Shah, and S. Agarwal, "Successful management of melanocytoma-associated choroidal neovascularization with photodynamic therapy," European Journal of Ophthalmology, vol. 16, no. 5, pp. 776-778, 2018.

[4] H. V. Tran, E. H. Bovey, S. Uffer, and L. Zografos, "Peripapillary choroidal neovascularization associated with melanocytoma of the optic disc: a clinicopathologic case report," Graefe's Archive for Clinical and Experimental Ophthalmology, vol. 244, no. 10, pp. 1367-1369, 2006.

[5] T. Kamisasanuki, E. Uchino, and T. Sakamoto, "Choroidal neovascularization of optic disk melanocytoma treated with bevacizumab," European Journal of Ophthalmology, vol. 22, no. 3, pp. 503-505, 2011.

[6] A. M. Al-Halafi, "Successful treatment of melanocytoma associated choroidal neovascular membrane with intravitreal bevacizumab," Saudi Journal of Ophthalmology, vol. 27, no. 2, pp. 117119, 2013.
[7] V. Batmanabane, M. Soman, and U. Nair, "Management of optic disc melanocytoma associated with choroidal neovascularisation and macular detachment," Journal of Ophthalmology of Clinical Research, vol. 2, no. 3, pp. 1-4, 2015.

[8] J. Urrets-Zavalia, N. Crim, E. Esposito, L. Correa, E. GonzalezCastellanos, and D. Martinez, "Bevacizumab for the treatment of a complicated posterior melanocytoma," Clinical Ophthalmology, p. 455, 2015.

[9] G. Rodrigues, T. Mendonca, S. Pai, and K. Amruthavalli, "Optic disc melanocytoma associated with choroidal neovascular membrane: an unusual presentation," Journal of Clinical and Diagnostic Research, vol. 12, no. 11, pp. D01-D02, 2018.

[10] H. E. Nasr, M. A. Nouh, R. A. Ahmed, and A. M. Elhusseiny, "Orbital melanocytoma: When a tumor becomes a relieving surprise," American Journal of Ophthalmology Case Reports, vol. 10, pp. 124-127, 2018.

[11] H. M. Bartlett, B. Willoughby, and N. Mandava, "Polypoidal choroidal vasculopathy in a patient with melanocytoma of the optic nerve," Retina, vol. 21, no. 4, pp. 396-399, 2001.

[12] M. Nicolás El-Haddad, F. Clement Fernández, E. PérezSalvador, and C. Martín Reyes, "Polypoidal choroidal vasculopathy in a patient with a melanocytoma of the optic nerve," Archivos de la Sociedad Española de Oftalmología, vol. 77, pp. 455-458, 2002.

[13] J. A. Shields, H. Demirci, A. Mashayekhi, and C. L. Shields, "Melanocytoma of optic disc in 115 cases: the 2004 Samuel Johnson Memorial Lecture, part 1," Ophthalmology, vol. 111, no. 9, pp. 1739-1746, 2004. 


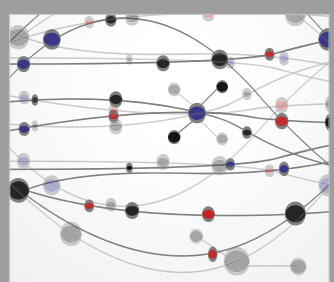

The Scientific World Journal
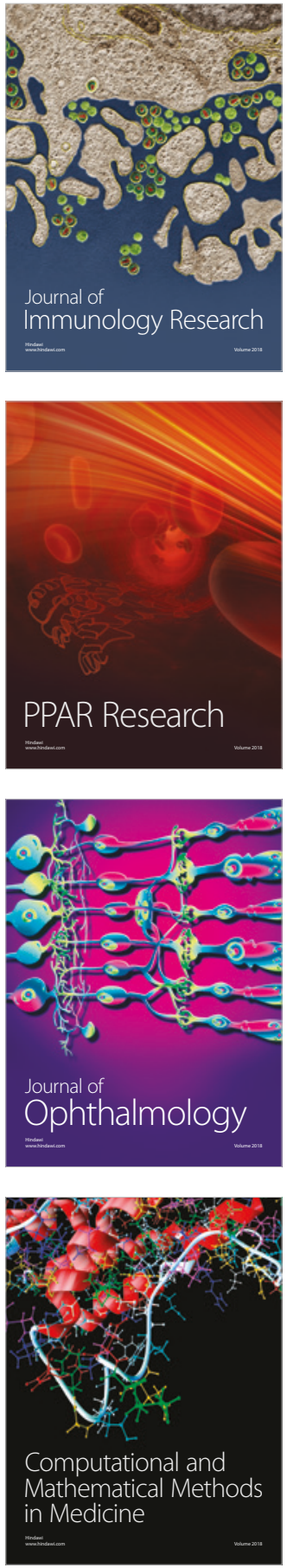



Gastroenterology Research and Practice

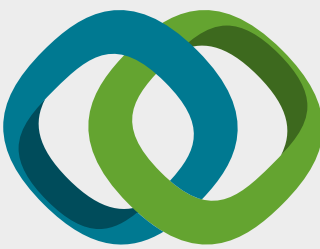

\section{Hindawi}

Submit your manuscripts at

www.hindawi.com
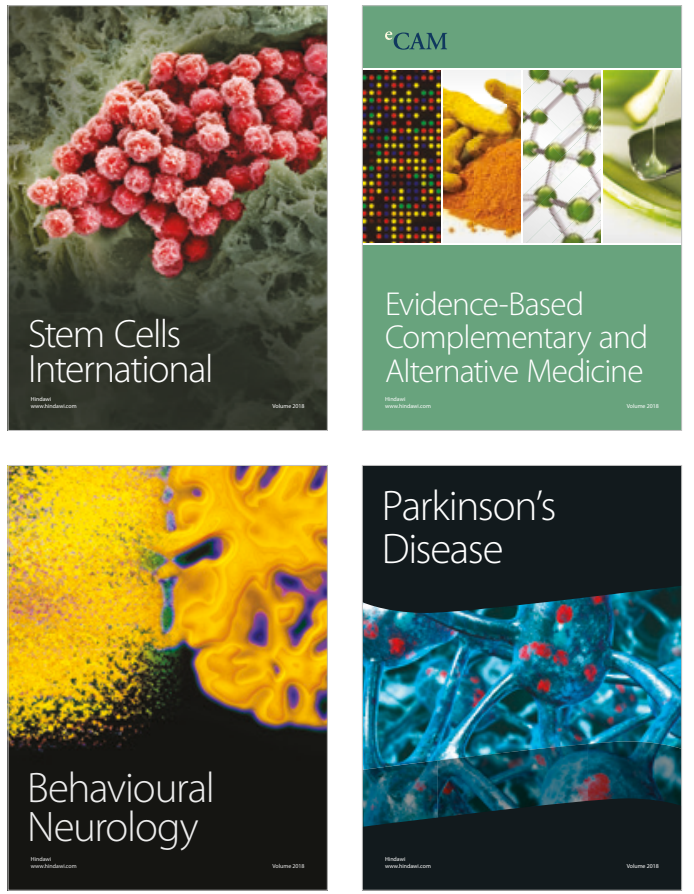

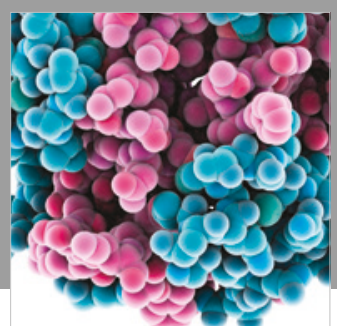

ournal of

Diabetes Research

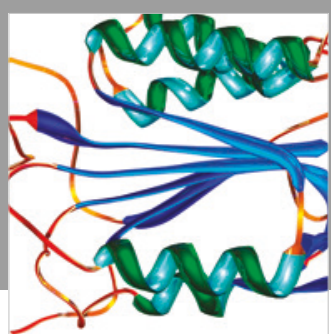

Disease Markers
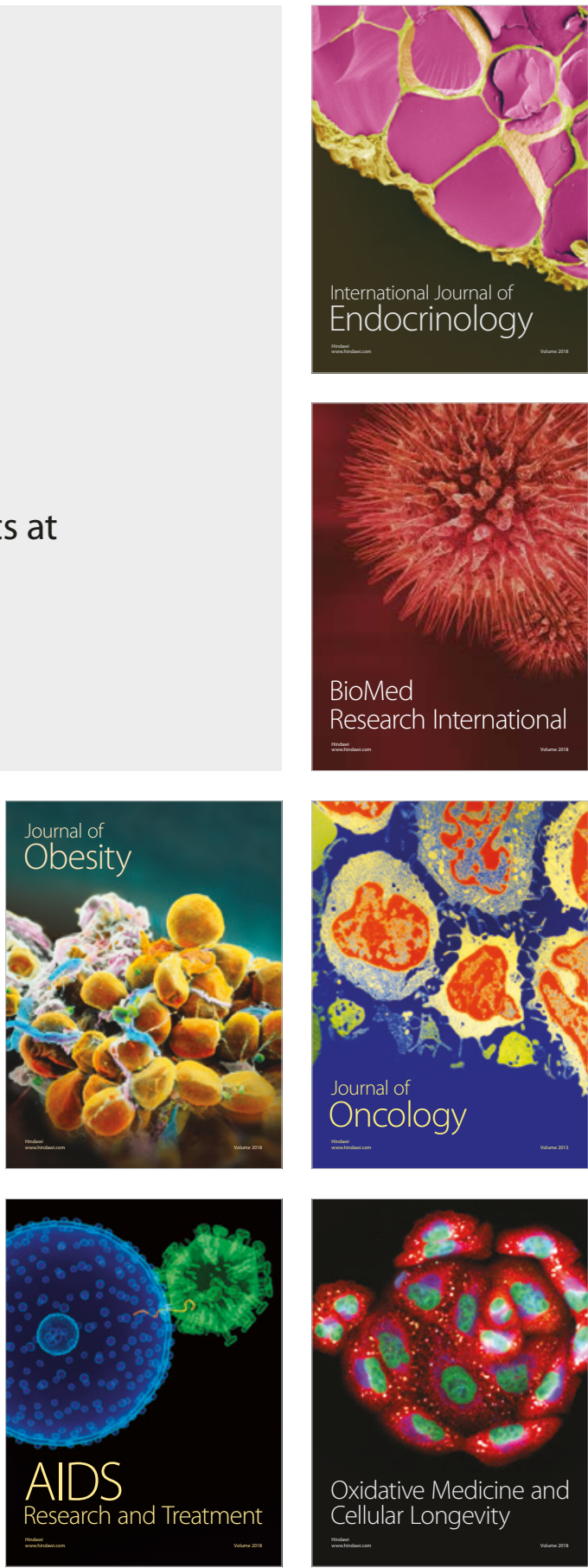